\title{
26. MIDDLE EOCENE DIATOMS FROM THE NORTH ATLANTIC, DEEP SEA DRILLING PROJECT SITE $605^{1}$
}

\author{
Andrew M. Gombos, Jr., Exxon Production Research Company ${ }^{2}$
}

\section{INTRODUCTION}

This report comprises a summary of the diatom biostratigraphy of the middle and lower Eocene biosiliceous section of Hole 605 (Cores 7-22), a presence/absence checklist of 25 common to abundant diatom taxa, and taxonomic references, notes, and illustrations of some of the more biostratigraphically significant diatom species discussed.

\section{Background}

Hole 605 is located on the upper continental rise of the Atlantic margin of the United States at $38^{\circ} 44.53^{\prime} \mathrm{N}$; $72^{\circ} 36.55^{\prime} \mathrm{W}$ in $2194 \mathrm{~m}$ of water (Fig. 1). A total of $816.7 \mathrm{~m}$ of sediment were penetrated; $662.4 \mathrm{~m}$ of section were cored and $532.08 \mathrm{~m}$ recovered.

Diatoms occur in varying abundance from Core 7 through Core 22 (Fig. 2). The interval is described as biogenic-silica-rich nannofossil chalk; foraminifers are significant components of the sediment in Cores 16 through 19 (see Site 605 report, this volume).

\section{Stratigraphic Framework}

The diatom-bearing interval in Hole 605 has been biostratigraphically dated by means of calcareous nannofossils (Applegate and Wise, this volume) and planktonic foraminifers (Hulsbos, this volume). Cores 7 through 21 were assigned to calcareous nannofossil Zone CP13 and Cores 22 and 23 to Zone CP12 of Okada and Bukry (1980). Zone CP12 extends down through Core 31, but that core is below the range of diatoms in this hole. The planktonic foraminiferal zone assignments are less precise because of the preservational state of the fossils. The interval from Core 7 through Core 12 is assigned to Zones P12 to P13 of Berggren (1972) and Cores 13 through 21 are assigned to Zones P10 to P13; Cores 22 and 23 are assigned to Zones P7 to P9.

\section{MATERIALS AND METHODS}

Thirty-two core samples were supplied to the author by S. W. Wise, Jr., for shore-based analysis (Table 1). All samples were processed and slides were prepared in the manner outlined by Gombos and Ciesielski (1983); that is the acidized sample material was sieved and slides were prepared from the fractions $<37 \mu \mathrm{m}$, from 37 to $63 \mu \mathrm{m}$, and $>63 \mu \mathrm{m}$.

In keeping with the concept of an "initial report," I undertook no exhaustive analysis of the diatoms in the middle Eocene of Hole 605. Instead, this report focuses on the sieved size fraction 37 to $63 \mu \mathrm{m}$, in

\footnotetext{
${ }^{1}$ van Hinte, J. E., Wise, S.W., Jr., et al., Init. Repts. DSDP, 93: Washington (U.S. Govt, Printing Office).

2 Address: Exxon Production Research Co., P.O. Box 2189, Houston Tx 77001.
}

which most of the common, well-preserved, biostratigraphically significant species (Table 2) tend to occur in Paleogene sediments.

Figure 2 charts the abundance of diatoms in the Eocene section of Hole 605 , as determined by smear slide analysis of bulk samples by shipboard sedimentologists. The figure also reflects the state of diatom preservation quite well. The best preservation was noted in the intervals where the diatoms are the most abundant.

Ten traverses of the $22 \mathrm{~mm} \times 22 \mathrm{~mm}$ cover slips were made at $\times 200$ magnification over each slide prepared from the $37-63-\mu \mathrm{m}$ fraction, and the presence of 25 biostratigraphically significant species was noted (Table 3). This survey was sufficient to permit the identification of previously defined diatom biostratigraphic intervals, and thus to date the section by means of fossil diatoms. More detailed taxonomic and compositional floristic studies are possible on the material from Hole 605 but are outside the scope of this report.

\section{DIATOM BIOSTRATIGRAPHY}

Gombos (1982) defined three diatom intervals for the early and middle Eocene in Hole $390 \mathrm{~A}$ on the Blake Plateau (Fig. 3). He identified the early Eocene Craspedodiscus moelleri interval (which is defined by the occurrence of C. moelleri, below the lowest occurrence of Brightwellia hyperborea) as equivalent to calcareous nannofossil Zone NP14 of Martini (1971) in its upper part. The NP14 zone of Martini (1971) is equivalent to the CP12 Zone of Okada and Bukry (1980).

Figure 4 illustrates the ranges, in Hole 605 , of five stratigraphically significant diatom species, including those which define the $B$. hyperborea interval and the $C$. moelleri interval. The abrupt termination of range lines below $346.51 \mathrm{~m}$ is certainly attributable to dissolution, because Pyxilla prolongata s.1., a robust, dissolution-resistant species, was observed in the sample from 349.51 m (Table 2). I have observed that $P$. prolongata s.l. is usually the last species remaining in Paleogene sediments in which the diatoms have undergone disintegration.

Thus, the only significant diatom datum observed in Hole 605 is the highest occurrence of $C$. moelleri. This datum can effectively be used to subdivide the $B$. hyperborea interval into two parts: an upper part characterized by $B$. hyperborea and a lower part characterized by the overlap in ranges from the highest occurrence of $C$. moelleri to the lowest occurrence of $B$. hyperborea. Because the lowest occurrence of $B$. hyperborea in Hole 605 is uncertain, it can only be securely stated that the diatom-bearing interval in Hole 605 is attributable to the Brightwellia hyperborea interval and is middle Eocene in age.

In Hole 390A, where the B. hyperborea and C. moelleri intervals were defined, a zone of siliceous and calcareous dissolution occurs near the early/middle Eocene boundary and truncates the lower range of $B$. hyperbo- 


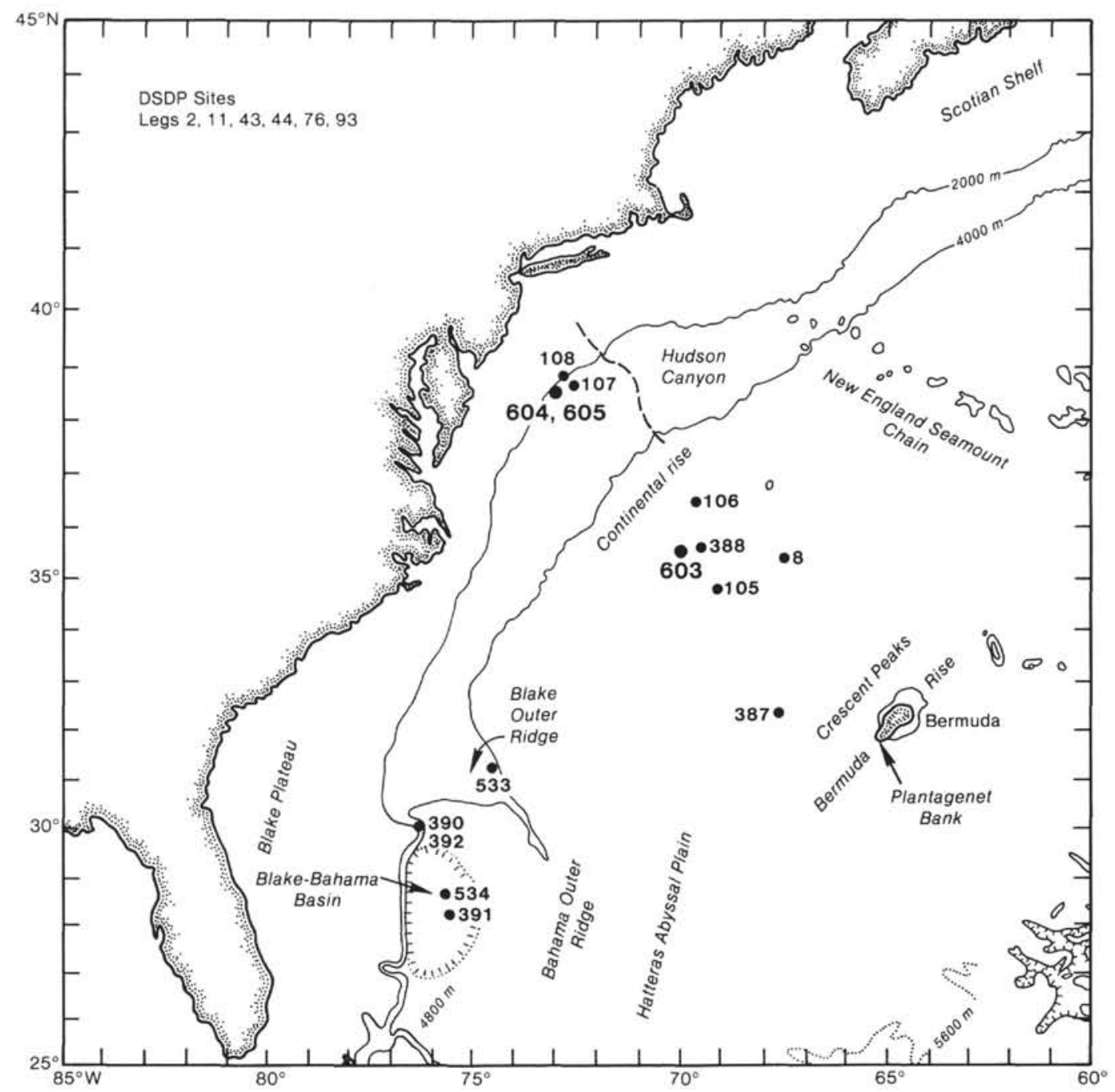

Figure 1. Location of Hole 605.

rea, as in Hole 605 (Gombos, 1982). It is apparent, then, that the boundary between the $B$. hyperborea and $C$. moelleri intervals occurs in a nebulous zone and cannot be accurately dated by secondary correlation to calcareous nannofossil zones, because we still do not know in which calcareous nannofossil zone the lowest occurrence of $B$. hyperborea occurs-though I think it falls in the upper part of Zone CP12 of Okada and Bukry (1980).

\section{REFERENCES}

Barker, J. W., and Meakin, S. H., 1944/45. New and rare diatoms. $J$. Quekett Microsc. Club, Ser. 4, 2(no. 1):18-22.

Berggren, W. A., 1972. A Cenozoic time-scale-some implications for regional geology and paleobiogeography. Lethaia, 5:195-215.

Brun, J., 1890-1893. Notes sur quelques espèces nouvelles. In Tempère, J. (Ed.), Le Diatomiste (Vol. 1):Paris (M. J. Tempère), 173-177.

Forti, A., 1909. Studi per una Monografia del genere Pyxilla (Diatomee) e dei generi affini. Nuova Notarisia, Ser. 20:5-24.

Gleser, S. I., 1975. To the revision of the genus Triceratium Ehr. sensu Hustedt, 1930 (Bacillariophyta). Bot. Zh. (Leningrad), 60(no. 9): 1304-1310.

Gombos, A. M., Jr., 1980. The early history of the diatom family Asterolampraceae. Bacillaria, 3:227-272.

1982. Early and middle Eocene diatom evolutionary events. Bacillaria, 5:225-242.
Gombos, A. M., Jr., and Ciesielski, P. F. 1983. Late Eocene to early Miocene diatoms from the southwest Atlantic. In Ludwig, W. J., Krasheninnikov, V. A., et al., Init. Repts, DSDP, 71: Washington (U.S. Gov. Printing Office), 583-634.

Greville, R. K., 1861-1866. Descriptions of new and rare diatoms. Ser. IXX. Trans. Microsc. Soc. London, N.S., 10:41-55.

, 1862. On the Asterolamprae of the Barbados deposit. Trans. Microsc. Soc. London, N.S., 10:41-55.

Grove, E., and Sturt, G., 1886-1887. On a fossil marine diatomaceous deposit from Oamaru, Otago, New Zealand. J. Quekett Microsc. Club, Ser. II, 2(16):321-330; 3(17)7-12; 3(18):63-78; 3(19):131148.

Heiberg, P.A.C., 1863. Conspectus Criticus Diatomacerum Danicarum: Kritisk Oversigt over De Danske Diatomeer: Copenhagen (Wilhelm Priors Forlag).

Martini, E., 1971. Standard Tertiary and Quaternary calcareous nannoplankton zonation. In Farinacci, A. (Ed.), Proc. II Planktonic Conf. Roma (Vol. 2): Rome (Edizioni Tecnoscienza), 739-786.

Okada, H., and Bukry, D., 1980. Supplementary modification and introduction of code numbers to the low-latitude coccolith biostratigraphic zonation, (Bukry, 1973; 1975). Mar. Micropaleontol., 5: 321-325.

Ross R., and Sims, P. A., 1980. Syringidium Ehrenb., Dextradonator Ross \& Sims, nov. gen. and Abas Ross \& Sims, nov. gen. Bacillaria, 3:115-127.

Schmidt, A., 1874-1959. Atlas der Diatomaceenkunde, begun by A. Schmidt, continued by Schmidt, M., Fricke, F., Müller, O., Heiden, H., and Hustedt, F.: Leipzig, Berlin (O.R. Reisland). 
Sheshukova-Poretskaya, V. S., and Gleser, S. I., 1964. Diatomeae marine novae e Palegeno Ucraineae. Akad. Nauk SSSR, Nov. Sist. Niz. Rast. Otdel. Bentii o Hisk: Moscow (Nauka), pp. 78-92.

Van Heurck, H., 1880-1885. Synopsis des Diatomées de Belgique: Antwerp (privately published).

Date of Initial Receipt: 26 December 1984

Date of Acceptance: 2 May 1985

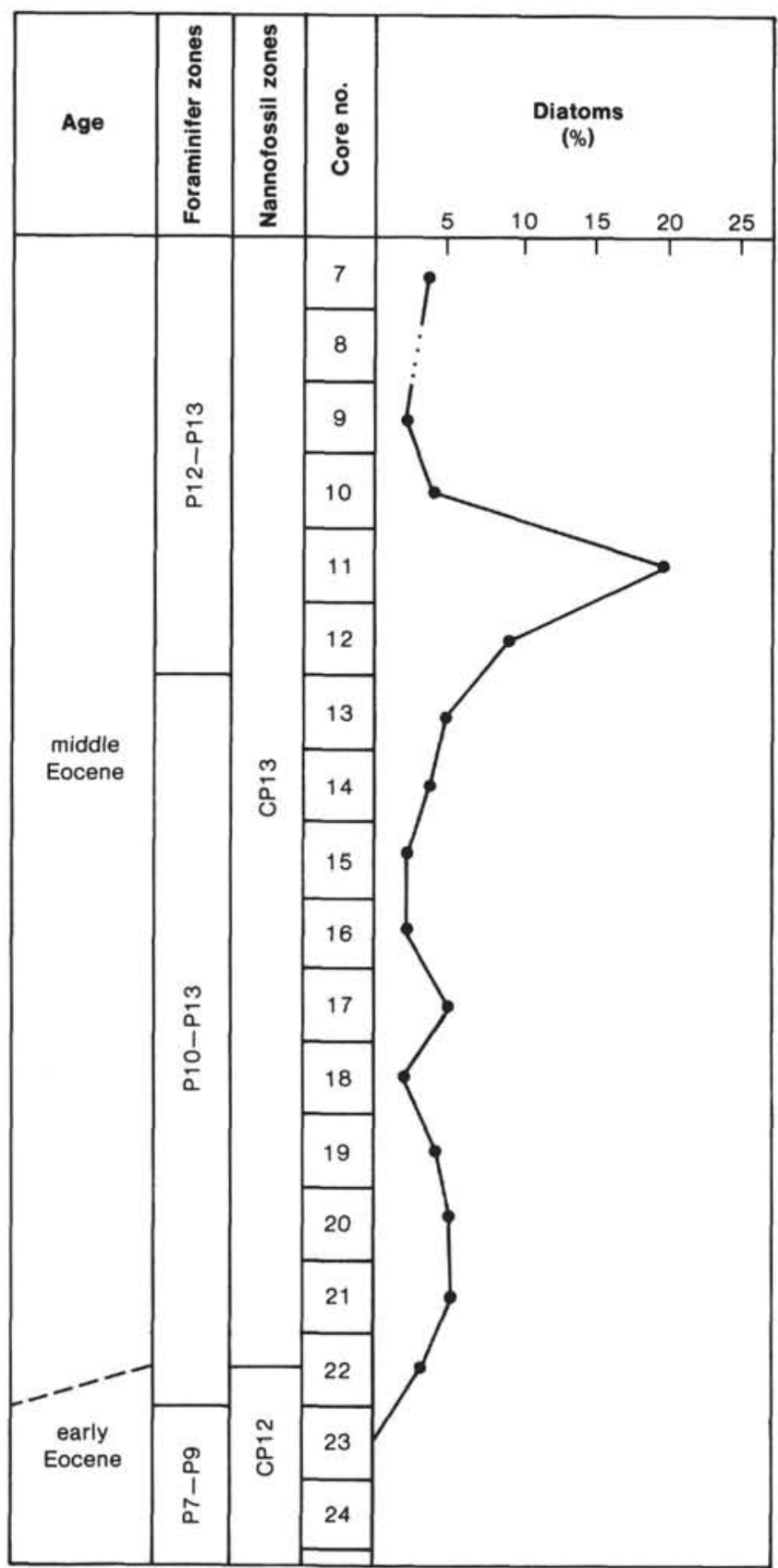

Figure 2. Percentage of diatoms among all microfossils in Cores 7-24 of Hole 605 , as determined from smear slide estimates.
Table 1. Samples examined for this study.

\begin{tabular}{lc}
\hline $\begin{array}{c}\text { Core-Section } \\
\text { (interval in cm) }\end{array}$ & $\begin{array}{c}\text { Sub-bottom } \\
\text { depth (m) }\end{array}$ \\
\hline $6-1,30-32$ & 193.01 \\
$6-3,30-32$ & 196.01 \\
$7-1,30-32$ & 202.61 \\
$7-3,30-32$ & 205.61 \\
$9-1,30-32$ & 221.81 \\
$9-3,30-32$ & 224.81 \\
$10-1,48-50$ & 231.59 \\
$10-3,30-32$ & 234.41 \\
$11-1,40-42$ & 241.11 \\
$11-3,30-32$ & 244.01 \\
$12-1,30-32$ & 250.61 \\
$12-3,30-32$ & 253.61 \\
$13-1,30-32$ & 260.21 \\
$13-3,30-32$ & 263.21 \\
$14-1,30-32$ & 269.81 \\
$14-3,30-32$ & 272.81 \\
$15-1,110-112$ & 280.21 \\
$15-3,110-112$ & 283.21 \\
$16-1,110-112$ & 289.81 \\
$16-3,110-112$ & 292.81 \\
$17-1,110-112$ & 299.41 \\
$17-3,110-112$ & 302.41 \\
$18-1,110-112$ & 309.01 \\
$18-3,110-112$ & 312.01 \\
$19-1,110-112$ & 318.61 \\
$19-3,110-112$ & 321.61 \\
$20-1,50-52$ & 327.61 \\
$20-3,50-52$ & 330.61 \\
$21-1,110-112$ & 337.81 \\
$21-3,110-112$ & 340.81 \\
$22-1,20-22$ & 346.51 \\
$22-3,20-22$ & 349.51 \\
\hline & \\
\hline
\end{tabular}

Table 2. Diatom species considered in this report.

Abas witti Ross and Sims, 1980 (18)

Asterolampra distincta Barker and Meakin, 1944/45 (16)

A. insignis Schmidt, 1888 (3)

A. jeffreysiana (Castracane) Gombos, 1980 (19)

A. marginata (Brightwell) Greville, 1862 (4)

A. ralfsiana Greville, 1862 (6)

A. transmarginata Gombos, 1980 (22)

A. vulgaris Greville, 1862 (7)

Brightwellia elaborata Greville, 1861 (8)

B. hyperborea Grunow in Van Heurck, 1883 (10)

B. spiralis Gleser in Sheshukova-Poretskaya and Gleser, 1964 (23)

Coscinodiscus bulliens Schmidt, 1886 (25)

Craspedodiscus ellipticus (Greville) Gombos, 1982 (11)

C. moelleri Schmidt, 1893 (21)

C. oblongus (Greville) Schmidt, 1886 (24)

C. splendidus (Greville) Gombos, 1982 (1)

Discodiscus tetraporus (Brun) Gombos, 1980 (17)

Melosira architecturalis Brun, 1892 (12)

Pseudotriceratium chenevieri (Meister) Gleser, 1975 (2)

Pyxilla gracilis Tempère and Forti in Forti, 1909 (15)

P. prolongata s.l., Brun, 1893 (14)

Rylandsia biradiata Greville, 1861 (5)

Trinacria excavata f. tetragona Schmidt, 1888 (9)

T. regina Heiberg, 1863 (19)

T. simulacrum s.l. Grove and Sturt, 1887 (20)

Note: See list of references for full citations. The number in parentheses following each species is keyed to the species number in Table 3. 
A. M. GOMBOS

Table 3. Stratigraphic occurrence of twenty-five common diatoms in Hole 605 .

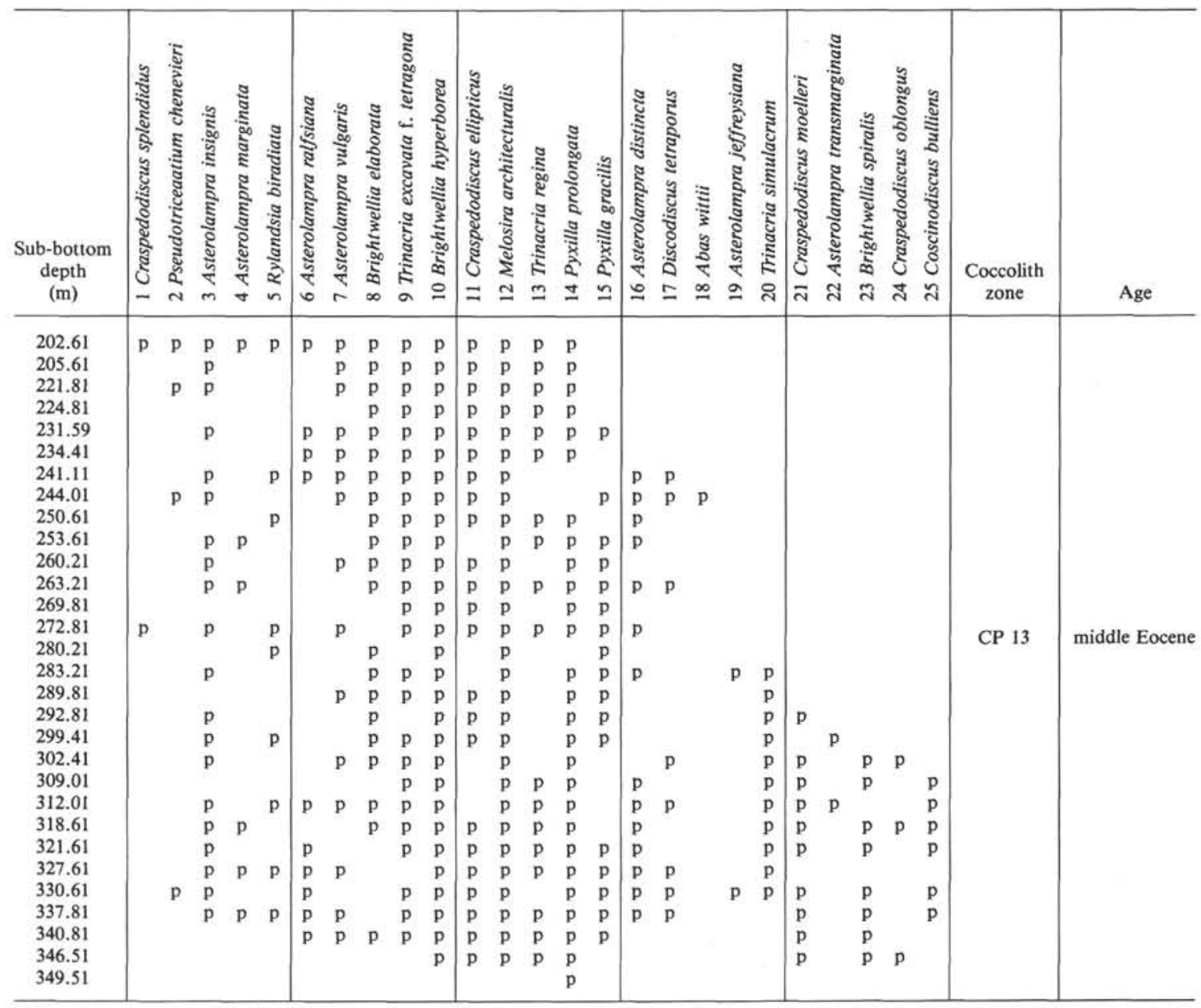

Note: $p=$ present; no symbol $=$ absent. 


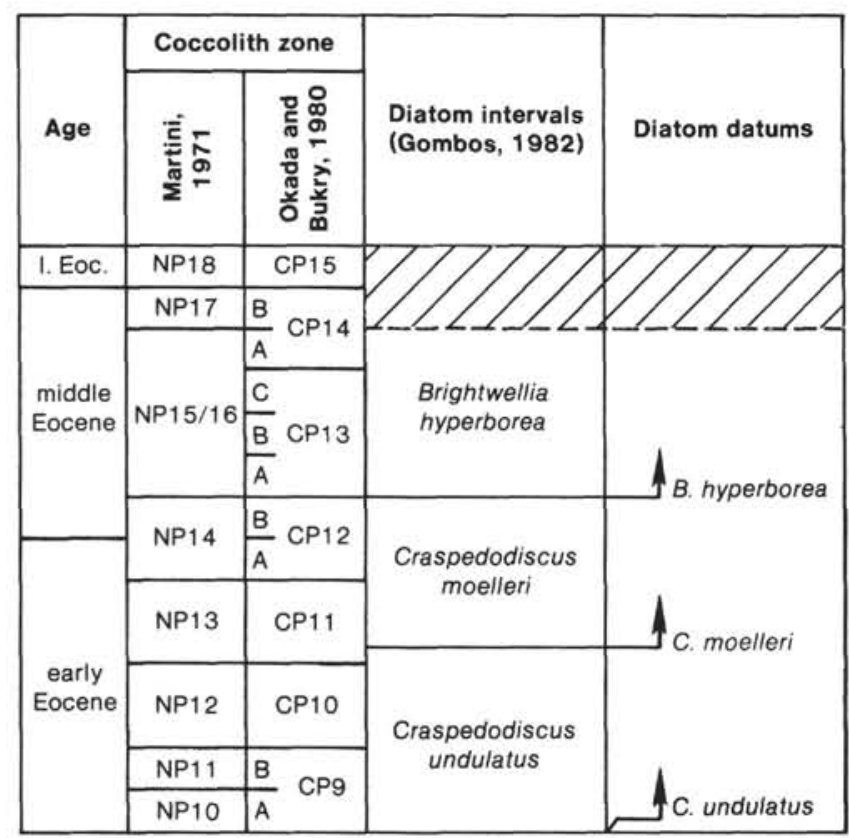

Figure 3. Definition, age significance, and correlation of the Eocene diatom intervals of Gombos (1982) with the coccolith zonations of Martini (1971) and Okada and Bukry (1980). Note that the base of the range of $C$. undulatus has been identified in NP10 in Denmark (Fenner, pers. comm., 1983). Hachured area $=$ no diatoms.

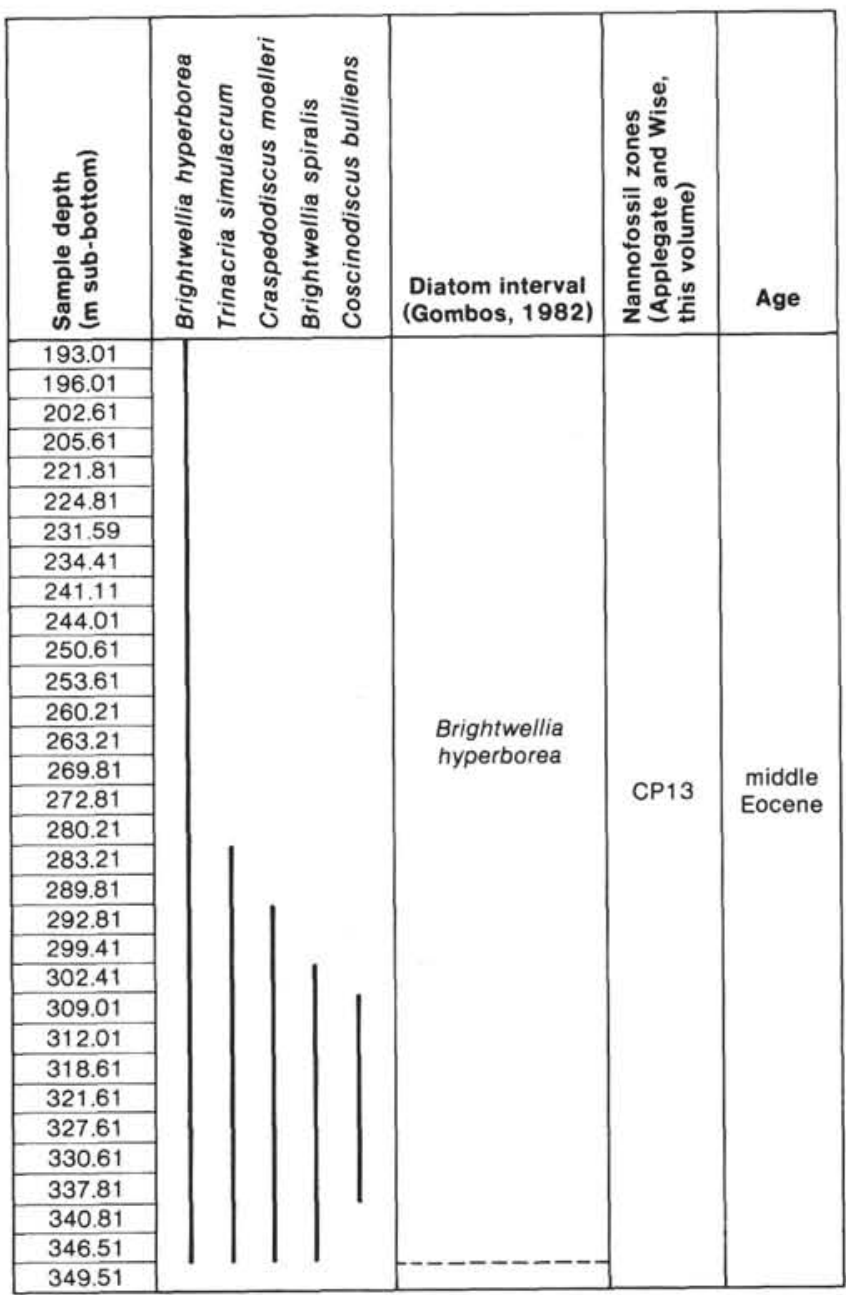

Figure 4. Stratigraphic occurrence of five stratigraphically significant diatom species in Hole 605. 


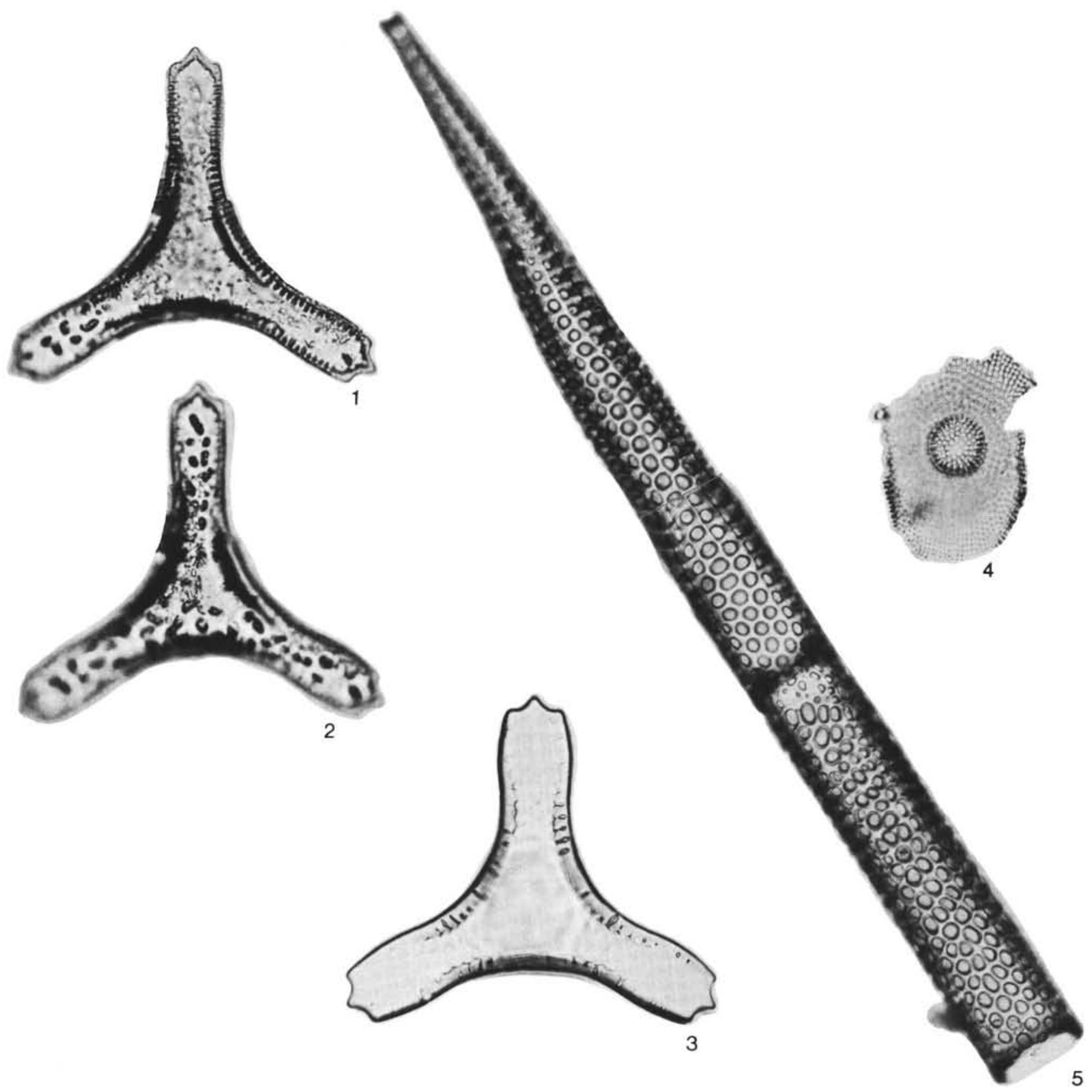

Plate 1. (All magnifications $\times 500$.) 1, 2. Trinacria simulacrum Grove and Sturt s.1. This is a variety which has numerous hooks scattered over the valve surface; Sample 605-19-1. 110-112 cm. 3. Trinacria simulacrum Grove and Sturt s.s., Sample 605-19-3, 110-112 cm. 4. Craspedodiscus oblongus (Greville) Schmidt; Sample 605-20-1, 50-52 cm. 5. Pyxilla gracilis Tempère and Forti; Sample 605-17-3, 110-112 cm. 

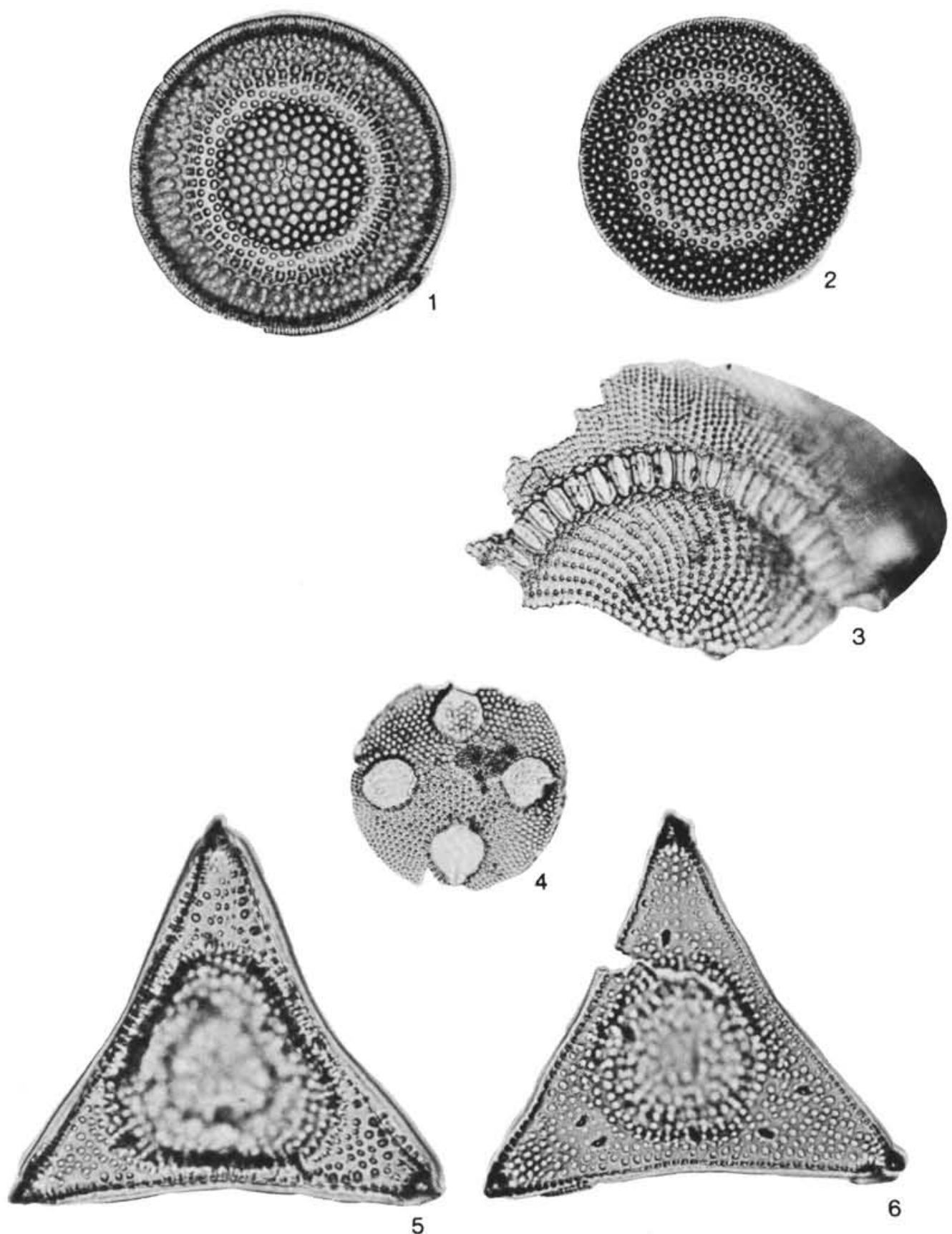

Plate 2. (All magnifications $\times 500$.) 1, 2 Craspedodiscus moelleri Schmidt, (1) Sample 605-21-3, 110-112 cm.(2) Sample 605-21-1, 110-112 $\mathrm{cm}$. 3. Brightwellia spiralis Gleser; Sample 605-19-1, 110-112 cm. 4. Discodiscus tetraporus Gombos; Sample 605-20-1, 110-112 cm. 5, 6. Trinacria cf. T. regina Heiberg; Sample 605-7-1, 30-32 cm. 